\title{
Developing regional operations research training capacity in South Asia
}

\author{
M.E. Khan \\ Population Council \\ James R. Foreit \\ Population Council \\ Sohini Roychowdhury \\ Population Council \\ F. Ram \\ Chander Shekhar
}

Follow this and additional works at: https://knowledgecommons.popcouncil.org/departments_sbsr-rh

Part of the Community Health and Preventive Medicine Commons, Demography, Population, and Ecology Commons, Family, Life Course, and Society Commons, Health Services Research Commons, International Public Health Commons, and the Medicine and Health Commons How does access to this work benefit you? Let us know!

\section{Recommended Citation}

Khan, M.E., James R. Foreit, Sohini Roychowdhury, F. Ram, and Chander Shekhar. 2007. "Developing regional operations research training capacity in South Asia," FRONTIERS Asia and Near East Region Final Report. Washington, DC: Population Council. 


\title{
Developing Regional Operations Research Training Capacity in South Asia
}

November 2007

Frontiers in Reproductive Health, Population Council

\author{
M. E. Khan* \\ Jim Foreit* \\ Sohini Roychowdhury* \\ International Institute of Population Sciences (IIPS), Mumbai, India
}

\author{
F. $\operatorname{Ram} * *$ \\ Chander Shekhar**
}

This study was made possible by the generous support of the American people through the United States Agency for International Development (USAID) under the terms of Cooperative Agreement No. HRN-A-00-98-00012-00 and Subaward No. AI03.57A. The contents are the responsibility of the FRONTIERS Program and do not necessarily reflect the views of USAID or the United States Government.

\section{(P) Population Council}

FRONTIERS

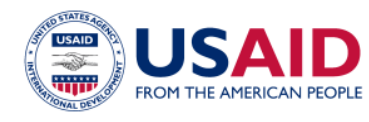




\begin{abstract}
The overall objective of this project was to create a self-sustaining regional operations research training and research center for South Asia at the International Institute of Population Sciences (IIPS), Mumbai, India. The project built IIPS capacity through training of trainers. Over a twoyear period, five discrete activities were performed. These included participation of IIPS staff in an OR workshop in Nepal; conducting two four-day OR workshops for program managers; one ten-day OR workshop for researchers; and a four-day scientific writing course for researchers and program managers to provide them with guidelines for preparing research articles and reports. IIPS is now offering a 20 hour course to its master degree students of population sciences. After training the trainees carried out 9 operations research studies and wrote 12 articles that were published in peer reviewed national and international journals.

Capacity building activities also produced an important multiplier effect in three additional organizations - The National Institute of Health and Family Welfare (NIHFW), New Delhi, India, the Center for Operations Research Training, Vadodara, India and the Medical College of Ahmadabad, India. NIHFW has introduced a paper on OR in the MD level course for students of Hospital Management and Epidemiology study, CORT is regularly offering courses in OR and scientific writing, and the Medical College of Ahmadabad is now including OR in its curriculum.
\end{abstract}




\section{TABLE OF CONTENTS}

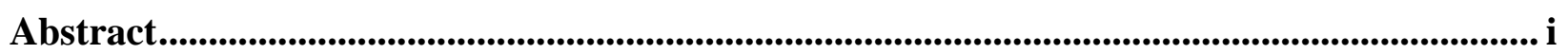

Table of Contents ............................................................................................................................ ii

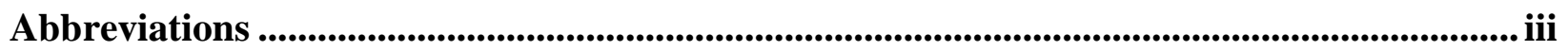

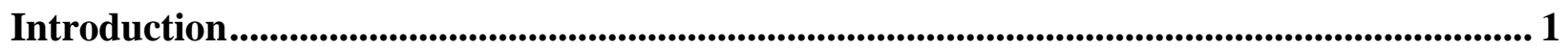

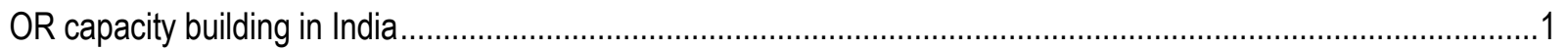

The International Institute of Population Sciences (IIPS) ................................................................................

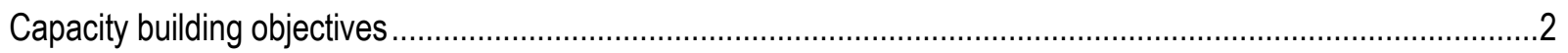

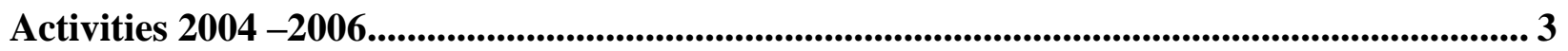

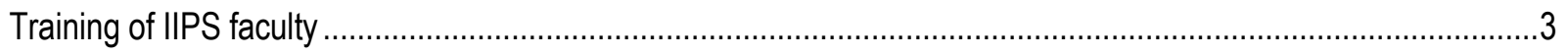

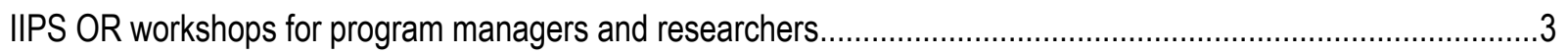

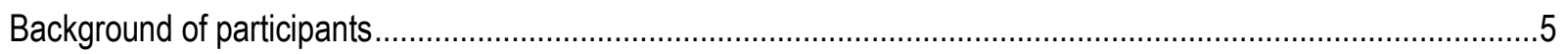

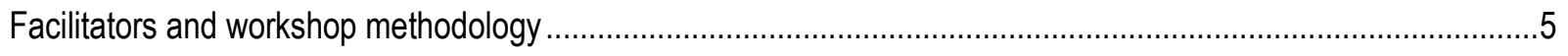

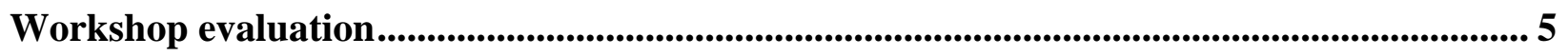

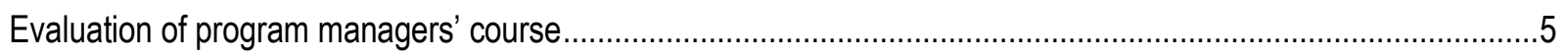

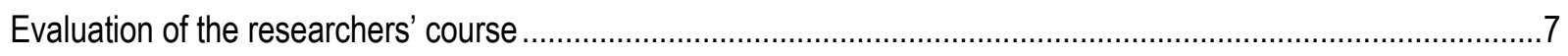

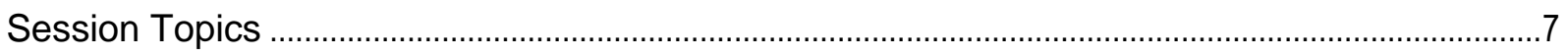

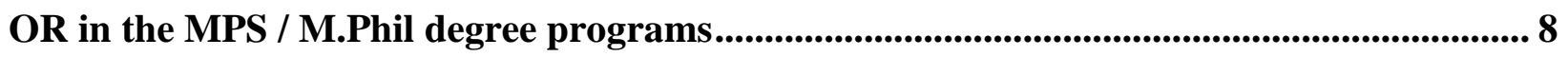

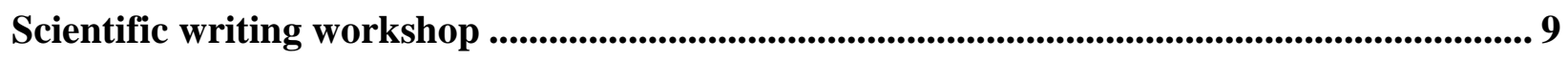

Follow-up Survey of Participants ..................................................................................... 11

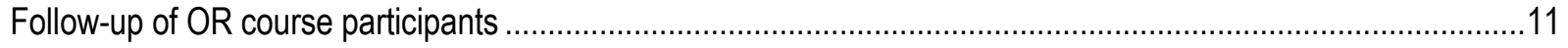

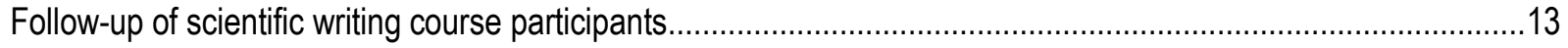

Multiplier Effects .................................................................................................................... 15

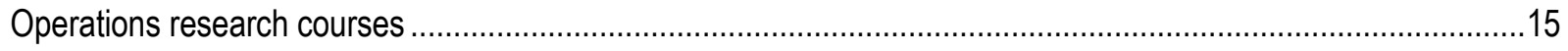

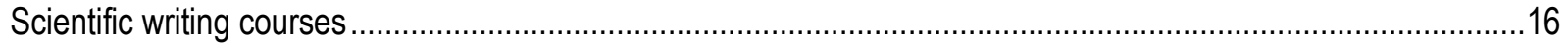

Discussion and Conclusion ................................................................................................................. 16

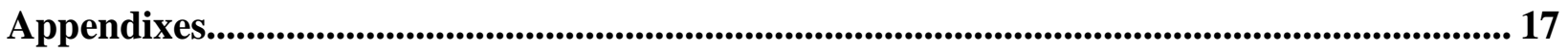




$\begin{array}{ll}\text { ABBREVIATIONS } \\ \text { AIDS } & \text { Acquired Immunodeficiency Syndrome } \\ \text { CDC } & \text { Cairo Demographic Center } \\ \text { DPS } & \text { Doctorate of Population Sciences } \\ \text { GOI } & \text { Government of India } \\ \text { HIV } & \text { Human Immunodeficiency Virus } \\ \text { IIPS } & \text { International Institute of Population Sciences } \\ \text { MPhil } & \text { Master of Philosophy } \\ \text { MPS } & \text { Master of Population Sciences } \\ \text { MOH\&FW } & \text { Ministry of Health and Family Welfare } \\ \text { OR } & \text { Operations Research } \\ \text { PHC } & \text { Primary Health Center } \\ \text { RCH } & \text { Reproductive and Child Health } \\ \text { RCQHC } & \text { Regional Center for Quality of Health Care } \\ \text { RH } & \text { Reproductive Health } \\ \text { SC } & \text { Sub center } \\ \text { TA } & \text { Technical Assistance }\end{array}$




\section{INTRODUCTION}

The goal of all FRONTIERS' capacity building partnerships is for OR training and research to become self-sustaining in selected institutions that can serve as national, regional or international resources. Pre-conditions for a sustainable OR training program include: (1) stable funding from multiple sources; (2) ability to draw regional participants to short courses; and, (3) working relationships with reproductive health service delivery programs. As part of FRONTIERS capacity building strategy, financial and technical support is provided for participants, teaching materials, course outlines and guest instructors. FRONTIERS-designed OR courses include a four-day workshop for program managers, a twoweek training course in operations research methods and OR proposal writing, and a oneweek workshop in the design of OR studies to increase financial sustainability. A course in scientific writing has also been developed. FRONTIERS financial support is usually limited to a two-year period, and OR training programs are expected to be self-sustaining at the end of that time.

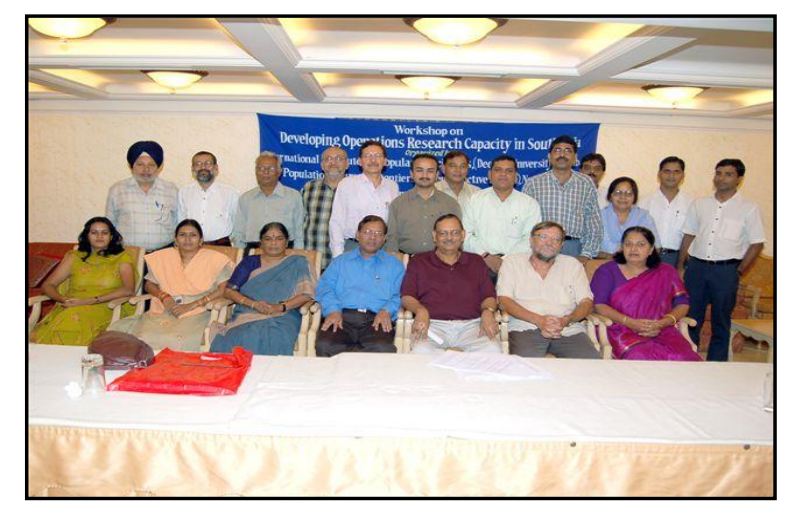

Participants at an OR workshop

\section{OR capacity building in India}

The Government of India's (GOI) Reproductive and Child Health program (RCH) is one of the largest in the world and it has been working to improve program quality and effectiveness. The GOI has undertaken a sensitization and skill development program for managers and is decentralizing the planning and implementation of the $\mathrm{RCH}$ program from state level to district level. At the same time, the GOI is attempting to innovate in program design and test alternative models for achieving program goals. Although there is great interest in demonstration and experimental projects, a lack of training in operations research hinders the use of intervention projects. Current Government of India Reproductive Health priorities in need of OR include:

- Integrating family planning and RH programs at the Primary Health / Sub Center (PHC/SC) level.

- Increasing access, use and quality of care

- Establishing and enhancing use of adolescent friendly clinics

- Developing and testing research tools for studying sexual health problems

- Introducing emergency contraception and no scalpel vasectomy

- Promoting dual protection

- Increasing efficiency of the RCH program.

Despite the GOI's best efforts, there is a lack of trained staff and training facilities in operations research in India. It is widely believed that the utilization of OR depends upon increasing local capacity to conduct OR and to present the findings which could be easily utilized by program managers for programmatic decision-making. This means increasing the consumer base of 
organizations that demand information generated through operations research and increasing the number and quality of staff and organizations capable of producing quality operations research.

The FRONTIERS capacity building strategy emphasizes collaboration with other organizations that can provide stable environments for training in applied research. Priority is given to activities with regional centers or institutions serving important, large-scale reproductive health programs and working in close collaboration with the Ministry of Health and Family Welfare $(\mathrm{MOH} \& \mathrm{FW})$. In view of this, an initiative was taken to create a self-sustaining operations research training and research centre for South Asia at the International Institute for Population Sciences, Mumbai, India.

\section{The International Institute of Population Sciences (IIPS)}

The International Institute for Population Sciences was established at Mumbai in July 1956 to serve as the regional center for training and research in population studies for the countries of the Asia and Pacific region. IIPS is an autonomous deemed university (a specialized university allowed to award degrees in a limited number of subjects) under the Ministry of Health and Family Welfare, Government of India. Besides teaching and research activities, the Institute provides consultant services to governments and non-governmental organizations. While IIPS is fully funded by MOH\&FW for its teaching and training activities, it has multiple sources of funding for research and special short-term trainings, including from the GOI, private foundations, international donor agencies, foreign governments and universities.

IIPS grants four academic degrees and conducts short-term training programs, seminars, symposia and workshops in population and related fields such as reproductive health.

The Institute also conducts a large number of research projects in fertility, mortality, and migration, and evaluations of population and reproductive health programs, adolescent sexuality and male reproductive health problems. All three National Family Health Surveys (NFHS) in India were conducted by IIPS.

In addition to the Government of India $\mathrm{RCH}$ program, reproductive health programs in Afghanistan, Bangladesh, Nepal, Vietnam and Cambodia also benefit from the Institute's regional role as a training and research center.

\section{Capacity building objectives}

The overall goal of the project was to institutionalize operations research in IIPS by building teaching and research capabilities of IIPS faculties and research team. Specific objectives included:

- To develop capacity within IIPS to teach and conduct OR in reproductive health

- To teach OR training courses for program managers

- To add an OR course to the MPS/MPhil and DPS programs

- To test the feasibility of self-financed OR courses for program managers (3-4 days) and researchers (10 days). 


\section{ACTIVITIES 2004 -2006}

\section{Training of IIPS faculty}

Dr. F. Ram, Head and Professor, Department of Fertility Studies, was invited to a ten-day OR workshop conducted by the FRONTIERS Program in Dhaka. Later Professor Ram and Dr. Chander Shekhar, Lecturer, Department of Population Policies and Programmes, attended a 10day course on Operations Research in Reproductive Health and HIV/AIDS. The program was conducted by FRONTIERS March 9-19, 2004 in Kathmandu, Nepal. In this workshop, Dr Chander Shekhar participated as a trainee, and Professor Ram as a resource person.

Participation in these workshops oriented IIPS staff to OR and the basic course. The workshop prepared them for teaching OR and conducting operations research. Professor Ram was also given the opportunity to co-facilitate one or more course sessions. The basic course brought researchers and program managers together and took them through the process of identifying researchable RH problems and developing an OR protocol for solving the problem. Topics covered in the basic OR course included:

- What is OR?

- Experimental design

- Qualitative research methods

- Introduction to economic evaluation of programs

- Research ethics

- How to make a good presentation.

Approximately half of the course was oriented to developing an actual OR proposal. After being trained and some experience in conducting the course, Professor Ram and Chander Shekhar, in collaboration with FRONTIERS staff and with other faculties of IIPS, organized four courses in OR and proposal development for a team of researchers and program managers. The role of FRONTIERS staff reduced with each workshop and by the fourth workshop, the IIPS staff were fully trained and able to conduct these courses independently.

\section{IIPS OR workshops for program managers and researchers}

IIPS conducted two four-day workshops on OR for program managers:

- Workshop on Developing Operation Research Capacity in South Asia for Program Managers April 12-15, 2004 in Khandala, India

- Workshop on Developing Operation Research Capacity in South Asia for Program Managers August 28-31, 2006 in Vadodara, India.

IIPS and FRONTIERS jointly facilitated the first workshop for program managers, whereas the second workshop required limited participation by FRONTIERS. Each course included approximately 20 reproductive health program managers from India and other regional countries. The workshop was designed for higher-level managers who have limited time for attending such training. Course objectives included (1) improving the ability of managers to evaluate OR proposals and results, and (2) preparing managers to play an active role in the OR process from 
problem identification to dissemination and utilization (Agendas for the two workshops are given in Appendixes Ia and Ib).

The workshops for program managers comprised 13 modules spread over four days each. The course included exercises, case studies and criticism of actual OR proposals and studies. The course sessions for the workshops were:

1. Course Introduction and Objectives

2. Experience Sharing

3. What is Operations Research?

4. Role of Manager in Operations Research

5. Identification of Problems and Solutions

6. Indicators: Outputs Outcomes Impacts
7. Demonstrating Causality

8. Research Design and Exercises

9. Ethics in OR

10. Dissemination and Utilization of OR

11. Resources for Program Managers

12. Research Proposal

13. Critical Review of Research

Proposal

IIPS then conducted a 10-day workshop on OR for researchers entitled 'Workshop on Developing Operations Research Capacity in South Asia for Researchers,' on December 8-18, 2004 in Khandala, India. The workshop for researchers was more exhaustive than those for managers. The course acquainted participants with the latest techniques in operations research which would help them to plan and conduct applied research in sexual and reproductive health programs. In addition, it also equipped researchers to help programs utilize findings.

The workshop comprised 19 modules spread across 10 days (see Appendix 1c for agenda). The course consisted of a series of lectures, exercises and group work. The sessions lasted for six to eight hours per day. Most of the course was devoted to discussion and exercises with presentation time held to a minimum. The course sessions for the workshop for researchers are listed below:

1. What is Operations Research?

2. Role of Manager in OR

3. Problem Identification

4. Components of OR Proposal

5. Indicators: Outputs Outcomes Impacts

6. Demonstrating Causality

7. Research Design

8. Sampling: Sample Size Determination

9. Methods of Data Collection: Qualitative

10. Methods of Data Collection:

Quantitative
11. Willingness to Pay Survey

12. Cost Analysis

13. Data Masking \& Management

14. Ethics in Operations Research

15. Situation Analysis

16. Data Analysis

17. Critical Review of Research Proposal

18. Dissemination and Utilization of OR

19. Upscaling of OR. 


\section{Background of participants}

There were 48 participants in the three workshops from 34 different government agencies, nongovernment organizations and academic institutions in South Asia. Most of the participants were from India, but three participants were from Nepal and one was from Bangladesh. Out of the 48 participants, $15(31 \%)$ were women, $25(52 \%)$ were researchers, $12(25 \%)$ were program managers and the remaining $11(23 \%)$ were evaluators from NGOs. Most managers were of senior level and were predominantly from the public health system. Among researchers, 49 percent came from research or academic institutions and 28 percent were from non-government organizations. Very few researchers had prior experience in intervention or operations research. Appendix II lists the participants.

\section{Facilitators and workshop methodology}

IIPS invited facilitators from the areas of operations research and social science research to conduct sessions. About half of the facilitators came from IIPS, and the rest from FRONTIERS, UNFPA, WHO, and the Government of India. The workshops were designed to include the staff of IIPS among the instructors to ensure their active involvement in conducting the workshops. Towards the close of the workshop (generally a day before the final day) participants were formed into groups and were given a research proposal to evaluate. This exercise, in general, was well liked by the participants. Participants were also trained to develop a proposal (or concept paper in case of the five-day workshop) for conducting OR on a real problem in their organization. The list of facilitators is given in Appendix III.

\section{WORKSHOP EVALUATION}

Course evaluations were designed to provide feedback to facilitators. Participants were asked to rate individual sessions in terms of organization and usefulness, and asked whether they would recommend the workshop to others. In total, 54 evaluations were received from the three workshops.

\section{Evaluation of program managers' course}

Twenty-five anonymous evaluations were received from the first workshop for program managers and 14 from the second workshop. Some sessions were common to both workshops while other sessions were only conducted in one workshop.

Overall, participants said that most of the sessions were clearly organized. Program manages, however, had difficulty in understanding the Cost analysis, Monitoring and Data Management, Sustainability and Qualitative methods sessions. These sessions were not included in the second program managers training workshop. Most participants found all the sessions useful to their work. However, some program managers felt that the sessions on Managers' Role in OR, Cost analysis and Qualitative methods were only somewhat useful. Results are presented in Tables 1 and 2 below. 
Many participants expressed their satisfaction with individual sessions. To quote one program manager, "I enjoyed components of an OR proposal, experimental design and the qualitative methods. Enjoyed group work very much". Another program manager said, "We enjoyed the interactive method of teaching".

Table 1: Program managers' evaluation on how the sessions were organized (Workshop 1 and 2 combined) $[n=39]$

\begin{tabular}{|l|c|c|c|c|}
\hline \multicolumn{1}{|c|}{ Session Topics } & $\begin{array}{c}\text { Very } \\
\text { clear }\end{array}$ & $\begin{array}{c}\text { To an } \\
\text { extent }\end{array}$ & $\begin{array}{c}\text { Not at all } \\
\text { clear }\end{array}$ & $\begin{array}{c}\text { Number of } \\
\text { respondents }\end{array}$ \\
\hline OR in reproductive health & 38 & 1 & 0 & 39 \\
Managers role in OR & 31 & 8 & 0 & 39 \\
Components of an OR proposal & 32 & 7 & 0 & 39 \\
Experimental design & 30 & 9 & 0 & 39 \\
Ethics of research & 34 & 5 & 0 & 39 \\
Identifying the program problem & 17 & 8 & 0 & 25 \\
Making a good presentation & 16 & 9 & 0 & 25 \\
Qualitative methods & 12 & 13 & 0 & 25 \\
Cost analysis & 7 & 18 & 0 & 25 \\
Sustainability & 12 & 13 & 0 & 25 \\
Situation analysis & 15 & 10 & 0 & 25 \\
Monitoring and data management & 5 & 20 & 0 & 25 \\
Output, outcome and impact & 11 & 3 & 0 & 14 \\
Causality & 9 & 5 & 0 & 14 \\
Dissemination and utilization & 12 & 2 & 0 & 14 \\
Budgeting & 10 & 4 & 0 & 14 \\
\hline
\end{tabular}

Table 2: Program managers' view on how useful the course components will be in their work (Workshop 1 and 2 combined) [ $=39]$

\begin{tabular}{|l|c|c|c|c|}
\hline \multicolumn{1}{|c|}{ Session Topics } & $\begin{array}{c}\text { Very } \\
\text { useful }\end{array}$ & $\begin{array}{c}\text { Somewhat } \\
\text { useful }\end{array}$ & $\begin{array}{c}\text { Not very } \\
\text { Useful }\end{array}$ & $\begin{array}{c}\text { No. of } \\
\text { respondents }\end{array}$ \\
\hline Managers role in OR & 20 & 16 & 3 & 39 \\
Experimental design & 27 & 11 & 1 & 39 \\
Ethics of research & 26 & 12 & 1 & 39 \\
Components of an OR proposal & 21 & 3 & 1 & 25 \\
Identifying the program problem & 21 & 3 & 1 & 25 \\
Making a good presentation & 18 & 4 & 3 & 25 \\
Qualitative methods & 13 & 11 & 1 & 25 \\
Cost analysis & 12 & 11 & 2 & 25 \\
Sustainability & 19 & 4 & 2 & 25 \\
Situation analysis & 20 & 4 & 1 & 25 \\
Monitoring and data management & 15 & 6 & 4 & 25 \\
Causality & 9 & 2 & 3 & 14 \\
Process dissemination & 9 & 5 & 0 & 14 \\
Writing a research proposal & 8 & 5 & 1 & 14 \\
Budgeting & 7 & 7 & 0 & 14 \\
\hline
\end{tabular}




\section{Evaluation of the researchers' course}

Fifteen evaluations were received from participants in the 10-day workshop for researchers. Overall, almost all the sessions were rated as excellent and useful. Most topics were found useful for their work (See Tables 3 and 4). However, clarity of presentation of 'Sample size determination' was marked as less clear by the majority of respondents. A majority of the respondents felt that such workshops should be conducted more frequently. As a result, IIPS intends to arrange self-financing short-term courses for South Asian health professionals in the near future. Topics that were rated as relatively less useful included Determination of sample size, Willingness to pay survey, Managers role in OR and Upscaling operations research.

Table 3: Researchers' evaluation on clarity of session presentations $(n=15)$

\begin{tabular}{|l|c|c|c|}
\hline \multicolumn{1}{|c|}{ Session Topics } & Very clear & $\begin{array}{c}\text { To an } \\
\text { extent }\end{array}$ & $\begin{array}{c}\text { Not at all } \\
\text { clear }\end{array}$ \\
\hline Introduction to OR in reproductive health & 15 & 0 & 0 \\
Mangers' role in OR & 12 & 3 & 0 \\
Researchers' role in OR & 14 & 1 & 0 \\
OR and research design & 12 & 3 & 0 \\
Indicators of OR & 12 & 3 & 0 \\
Causality & 11 & 4 & 0 \\
Dissemination and utilization of OR & 11 & 4 & 0 \\
Situation analysis & 13 & 2 & 0 \\
Sample size determination & 4 & 8 & 0 \\
Willingness to pay survey & 14 & 1 & 0 \\
Data masking and data analysis & 9 & 5 & 0 \\
Components of an OR proposal & 13 & 2 & 0 \\
Ethics in RH research & 14 & 1 & 0 \\
Budgeting & 12 & 3 & 0 \\
\hline
\end{tabular}

Table 4: Researchers' view on how useful course components will be in their work $(n=15)$

\begin{tabular}{|l|c|c|c|}
\hline \multicolumn{1}{|c|}{ Session Topics } & Very useful & $\begin{array}{c}\text { Some what } \\
\text { useful }\end{array}$ & $\begin{array}{c}\text { Not very } \\
\text { useful }\end{array}$ \\
\hline Mangers' role in OR & 9 & 6 & 0 \\
Intervention research & 13 & 2 & 0 \\
Causality in social research & 10 & 4 & 1 \\
Process of dissemination & 12 & 3 & 0 \\
Writing a research proposal & 14 & 1 & 0 \\
Ethics in RH research & 11 & 4 & 0 \\
Budgeting & 11 & 4 & 0 \\
Situational analysis & 10 & 4 & 1 \\
Sample size determination & 6 & 8 & 1 \\
Willingness to pay survey & 9 & 6 & 0 \\
Up scaling of OR & 8 & 7 & 0 \\
Data masking and data analysis & 9 & 4 & 2 \\
\hline
\end{tabular}




\section{OR IN THE MPS / M.PHIL DEGREE PROGRAMS}

IIPS introduced a 20-hour advanced OR course to the MPS/MPhil curricula (see below) in the 2006-07 academic year. The course covers the basic concepts of OR. Lectures and materials were based on the short courses in OR and on existing subjects. The aim of the course is not only to help students to develop academically, but also to provide marketable skills in a country where intervention/action-oriented research is increasingly executed by the public and private sectors. FRONTIERS supplied all teaching materials and TA for curriculum development; except for one guest lecture, all instruction was given by IIPS faculty.

\section{Optional Paper Operations Research in Reproductive Health}

(1) Definition of OR

(a) What is Operations Research

(b) Focus and Objective of Operations Research

(c) Types and Examples of Operations Research

(2) Role of Researchers and Managers

(3) Components of OR proposal

(4) Identification of Problem and Solution

(a) Identification and Definition

(b) Justification

(c) Alternative Solution

(d) Indicators- Outputs, Outcomes and Impacts

(5) Causality (Randomize Experimental Design)

(a) Pretest-Post test Control Group Design

(b) Post test -only Control Group Design

(c) Multiple Treatment Design

(6) Quasi/Non-Experimental Design

(a) Non-Experimental Control Design

(b) Time Series, and Before and After Design

(7) Inferential Statistics in Operations Research

(a) $\left(\mathrm{X}^{2}, \mathrm{t}, \mathrm{F}\right)$-tests

(b) Deciding Sample Size in case of Different Experimental Design

(c) Linking Different Design and Statistical Test

(8) Study Design Exercises

(9) Ethics in Operations Research

(a) ICMR Guidelines

(b) International Perspectives

(c) Case Studies

(10) Utilization and Dissemination, and Process Documentation

(11) Critiques to OR proposal
(20 Hrs) 
Essential Reading List:

Fisher, Andrew A., J. Foreit, J. Laing, J. Stoeckel and J. Townsend 2002: Designing

HIV/AIDS Intervention Studies-An Operations Research Handbook, Population Council, New

York.

Foreit, James R. and Tomas Frejka 1998: Family Planning Operations Research-A Book of Readings, Population Council, New York

Kish, Leslie 1965: Survey Sampling, New York, John Wiley and Sons.

\section{SCIENTIFIC WRITING WORKSHOP}

Writing reports and journal articles are important skills for all researchers. We have found that scientific writing skills are limited among developing country researchers, resulting in the loss of much good research. In response to a growing demand for improving writing skills, a course on "Scientific Writing for Reproductive Health Programs" was jointly organized by IIPS, FRONTIERS, and WHO at the IIPS from 16-19 May, 2006. The course consisted of 14 modules spread over four days, including lectures and interactive exercises. Every day different groups formed to complete exercises. This provided the participants with the opportunity to interact with each other and build partnerships. The course sessions were:
1. Course Introduction
2. Principles of Authorship
3. How to Choose a Journal
4. Selecting a Title
5. Abstract
6. Introduction
7. Methods Section
8. Presenting Data
9. Results Section
10. Discussion Section
11. Preparing References
12. Publication Ethics
13. Responding to Reviewers
14. Wrap-up

Twenty-two participants attended the scientific writing course. Almost all the participants were researchers in the area of reproductive health. The majority (15 participants) were from local research institutions in Mumbai, the remaining seven participants were from Delhi, Vadodara and Pune. The participants came from disciplines such as population studies, demography, medicine, sociology, social work, and economics. Facilitators were from IIPS, FRONTIERS, and WHO. A complete list of the participants is given in Appendix IV. The teaching materials were developed by FRONTIERS and WHO, and are now available on the internet at: http://www.popcouncil.org/frontiers/ScienceWriting/index.htm

An evaluation was conducted daily. Participants evaluated the organization of each session and its usefulness. In case any topic was not clear during the session conducted in the previous day or a participant needed more clarity on a specific topic, the first half hour of the next day was devoted to addressing those issues. As can be seen in Table 5, overall the evaluation of each topic was positive. 
Table 5: Participant evaluation of the scientific writing course

\begin{tabular}{|l|c|c|c|}
\hline $\begin{array}{c}\text { Day and session wise feedback of } \\
\text { the participants }\end{array}$ & \multicolumn{3}{|c|}{$\begin{array}{c}\text { MUMBAI } \\
\text { (N=19) }\end{array}$} \\
\hline \multicolumn{1}{|c|}{ Sessions } & Excellent & Good & Average \\
\hline Day 1 & - & - & - \\
Introduction to the course & 7 & 11 & 1 \\
Authorship & 7 & 11 & 1 \\
How to choose journal & 11 & 7 & 1 \\
Choosing title & 15 & 4 & 0 \\
How to write abstract & & & \\
\hline Day 2 & - & - & - \\
Abstract - exercise & 13 & 5 & 1 \\
Writing the introduction & 13 & 5 & 1 \\
Writing the methods section & 12 & 6 & 1 \\
\hline Day 3 & 11 & 7 & 1 \\
Presenting data & 11 & 7 & 1 \\
Writing the results section & & & \\
Writing the discussion section & 11 & 7 & 1 \\
& 10 & 7 & 2 \\
\hline Day 4 & - & - & - \\
Preparing references & 9 & 9 & 1 \\
Publication ethics & & & \\
Criticism of published paper & & & \\
Responding to reviewers \& editors & &
\end{tabular}

Participants also commented on the sessions and on the course. Overall, the participants liked the course and rated the session on writing an abstract the highest followed by writing the methods and introduction sections. Almost all the participants said that the course was very useful. Many participants intended to organize the course in their respective institutions. In response to what they liked the most in the course, participants stated:

'The course was made interesting with exercise and was interactive as well.'

'Everything was important but the most useful was how to write an abstract.'

'Introducing the concept of steps-like key for scientific writing was excellent.'

In response to what they did not like in the course, the comments of participants were:

'Examples focus only on operations research.'

'The sessions were at times too long.'

Participants also provided suggestions on how to improve the course. Some of the comments are reproduced below.

"More time should be allocated for the exercise."

'Variety of research and data sources should be taken as examples so that it is more holistic in nature.' 


\section{FOLLOW-UP SURVEY OF PARTICIPANTS}

\section{Follow-up of OR course participants}

Forty-seven managers and researchers who attended the three OR courses were e-mailed a structured questionnaire 6-14 months after their participation in the workshop. Two participants from the Center for Operations Research and Training (CORT) who had attended the IIPS course in turn organized two workshops on OR for participants from India, Pakistan and Bangladesh.

Twenty-five participants in the first CORT OR workshop were also e-mailed the questionnaire to receive feedback on how they used their skills. Inclusion of CORT's OR trainees in the follow up surveys provided feedback from a larger number of participants who had attended OR training courses. Of 72 participants who were mailed the questionnaire, 43 responded for a response rate of 60 percent, which is quite high for a mail survey.

Of the 43 participants who responded 23 (53\%) were from research institutions followed by nine (21\%) from government health programs, eight (19\%) from universities and three (7\%) from service delivery NGOs. The key points that emerged from the analysis are listed below:

$>$ The main job responsibility of more than half of the 43 participants was research and monitoring/evaluation (60\%). Other occupations included reproductive health consultant, and the directors of research institutions.

$>$ Thirty-seven participants (86\%) had never attended an OR workshop before. Only six (14\%) had attended one or more OR workshop.

$>$ Thirty-four participants (79\%) felt that the training was very useful while nine (21\%) felt that it was somewhat useful.

$>$ Twenty-seven participants (63\%) said they had the opportunity to use skills learned at the workshop in their jobs, through teaching, research and program improvement, while 16 participants (37\%) said that they have not had an opportunity to use their skills.

$>$ Eighteen participants $(42 \%)$ said that they had used the training in conducting research. Twelve out of the 18 participants provided the titles of their research studies. Nine of the 12 studies were intervention studies (See Appendix V).

$>$ Thirteen participants had used their skills for teaching. Of them, nine (70\%) taught the OR course to undergraduate and/or postgraduate students. One taught the course to other faculty in her university. Three participants from CORT taught the course to social scientists and program managers from India, Pakistan and Bangladesh.

\section{Participants used the skills learned to:}

$$
\begin{array}{ll}
\checkmark & \text { Develop18 OR proposals } \\
\checkmark & \text { Conduct nine OR studies } \\
\checkmark & \text { Teach OR courses to university students } \\
\checkmark & \text { Organize two OR training workshops for } \\
& \text { national and international participants } \\
\checkmark & \text { Monitor/Improve Program } \\
\checkmark & \text { Plan/Develop Program }
\end{array}
$$


$>$ One trainee from the National Institute of Health and Family Welfare, subsequently (with very limited TA from FRONTIERS) organized a six-day training course for population and reproductive health program officers from 35 state governments. Subsequently, an OR course was introduced into the institute's hospital management and epidemiological programs.

$>$ Ten participants $(23 \%)$ said that they had used the training in various stages of program development. The following examples were provided by the 10 participants:

"Training was used to decide alternative course of action and to identify problems and find solutions in service delivery program."

"The training benefited me greatly in developing new project proposals."

"It helped me in improving study design while writing proposal. It also helped me at the time of analysis and report writing"

"My newly acquired skills helped me in developing intervention package for married adolescent program. Helped in preparing research proposal on increasing utilization of HIV/AIDS Voluntary counseling, testing and care services in rural Maharashtra"

"I used the training on research ethics as a member of the newly formed Institutional Review Board for Atriums Bio at Vishakapatnam."

"I had received the training just when the project SHRC (funded by DFID) was undergoing a transition, and the organization which I am serving had to re-bid for it with improved plan of implementation. Since the project was all about providing technical assistance, capacity building and knowledge management support to various partners, and operations research being an integral part of it, the training was very useful in conceptualizing certain ideas that had to be put in the program management part of the proposal."

"I used my learning on cost analysis, timeline design and MIS planning that were taught at the course in my work."

"Based on the understanding of the program's gap/implementation strategy, I utilized my theoretical skills in program strategy development and conducted OR study as well as utilized my skills in the ongoing OR."

"I designed an adolescent's media research programme"

> Participants were asked whether the workshops were useful and should continue. Twentyeight participants $(65 \%)$ said that the training was useful and should continue but with some modifications while 15 respondents (35\%) felt that the course was useful and there was no need for modification. The suggested changes are presented in Table 6. 
Table 6: Suggested modifications by course participants

\begin{tabular}{|l|c|}
\hline \multicolumn{1}{|c|}{ Modifications suggested } & $\begin{array}{c}\text { Number of } \\
\text { participants (N=28) }\end{array}$ \\
\hline Include more exercises, case studies and examples & 10 \\
\hline Include field visits in the training & 4 \\
\hline $\begin{array}{l}\text { Allocate more time to sessions like development of OR proposal, utilization } \\
\text { of research, data analysis }\end{array}$ & 6 \\
\hline Make it more participatory & 2 \\
\hline Increase training period & 3 \\
\hline Reduce training period & 3 \\
\hline $\begin{array}{l}\text { Provide participants opportunity of hands-on training for conducting OR } \\
\text { after the workshop }\end{array}$ & 3 \\
\hline $\begin{array}{l}\text { Focus more on policymakers and medical college faculties. Participants } \\
\text { should bring an OR proposal for critiquing }\end{array}$ & 2 \\
\hline Other & 7 \\
\hline
\end{tabular}

${ }^{*}$ Number adds to more than 28 because of multiple suggestions

\section{Follow-up of scientific writing course participants}

FRONTIERS helped sponsor two workshops on "Scientific Writing for Reproductive Health Programs" in India in 2006. The first was organized by IIPS, FRONTIERS and WHO in Mumbai from May 16 to 19, 2006, and the second was organized by CORT, also in collaboration with FRONTIERS and WHO, from May 22 to 25, 2006 in Vadodara.

In February 2007, CORT conducted a second scientific writing workshop using the FRONTIERS/WHO curriculum, but without external resource persons. Twenty-six university faculty, researchers and a few program managers participated in the workshop. To obtain feedback on the usefulness of the writing course, a follow-up evaluation was carried out 6-14 months after completion of the three (IIPS and two CORT) writing courses. Out of the 57 trainees who had attended the workshops 42 (74\%) provided feedback. Table 7 shows the institutional affiliation of the respondents.

Table 7: Institutional affiliation of participants

\begin{tabular}{|l|c|}
\hline \multicolumn{1}{|c|}{ Institution affiliation } & $\begin{array}{c}\text { Number of participants* } \\
\mathbf{N = 4 2}\end{array}$ \\
\hline Government health program & 7 \\
\hline University teaching & 15 \\
\hline Research institution & 10 \\
\hline NGO (research) & 7 \\
\hline Other & 3 \\
\hline
\end{tabular}


The salient points that emerged from the evaluation include:

$>$ Almost half of the 42 participants were university faculty, and a further one third were engaged in monitoring / evaluation.

$>$ Thirty-nine participants (93\%) said that they had never attended a scientific writing training workshop before.

$>$ Twenty-six participants $(62 \%)$ felt that the training was very useful while 15 participants $(36 \%)$ felt that the training was somewhat useful. One participant said that the training was not useful.

Twenty participants $(48 \%)$ used their skills to write journal articles and reports.

Appendix VI lists the articles and reports.

$>$ Nine participants $(21 \%)$ taught the scientific writing course, almost all to undergraduate and/or postgraduate students. One taught the

\begin{tabular}{|l} 
Skills learned were used in: \\
$\checkmark$ Teaching scientific writing courses to \\
university students \\
$\checkmark$ Organizing scientific writing training \\
workshops for national and \\
international participants \\
$\checkmark$ Publishing 12 articles in journals \\
$\checkmark$ Writing abstracts \\
$\checkmark$ Writing reports/updates \\
\hline
\end{tabular}
course to other faculty.

Comments from five respondents who went on to organize scientific writing activities include:

'Along with two other colleagues I conducted training for 30 participants in collaboration with Indian Pharmacological Society, Ahmadabad.' (Faculty member of medical college Ahmadabad)

'I organized a training program for 24 people on scientific paper writing for medical teachers at BJ Medical College, Ahmadabad.' (Professor of B.J Medical College)

'Organized two workshops for faculty in another department of my institution on scientific writing'

'We organized training program for 15 participants from India and Pakistan in Vadodara.'

'I organized training for counselors on report writing in Maharashtra State Aids Control Society.' 
$>$ Participants were asked whether the training was useful and should continue. Twenty-three participants (55\%) said that the training should continue in its present format while 19 participants $(45 \%)$ said that the course should continue with some modifications.

$>$ Participants suggested the modifications shown in Table 8 below.

Table 8: Suggested modifications to scientific writing course

\begin{tabular}{|l|c|}
\hline \multicolumn{1}{|c|}{ Modifications suggested } & $\begin{array}{c}\text { Number of participants } \\
(\mathbf{N = 1 9 )}\end{array}$ \\
\hline No change /modification required & 23 \\
\hline More practical exercises and hands-on training & 11 \\
\hline Separate workshops for medical and social researchers & 4 \\
\hline Duration should be made shorter & 2 \\
\hline Include biostatistics and medical statistics in the course & 2 \\
\hline Training should be residential & 2 \\
\hline Other & 3 \\
\hline
\end{tabular}

\section{MULTIPLIER EFFECTS}

Operations research capacity building activities had both direct and multiplier effects. Among the direct effects were that the OR and Scientific Writing courses were taught by IIPS and OR was institutionalized into their Masters Curriculum. Although difficult to quantify, use of the skills acquired by participants in the IIPS courses in post-course research and writing can also be considered direct effects.

Somewhat easier to quantify are the multiplier effects of the IIPS activities. Participants at IIPS courses went on to replicate the courses in their own institutions, thereby enhancing the size of the OR and scientific writing skills pool beyond that of the IIPS courses themselves. Notable multiplier effects include:

\section{Operations research courses}

- The OR course for managers was replicated (using FRONTIERS materials) twice by CORT in Vadodara, India, in 2006 and 2007; the course is now offered annually. Participants came from Pakistan and Bangladesh as well as India. CORT specializes in short term training in subjects related to applied research and health programs.

- The Institute of Health and Family Welfare, arguably the most important reproductive health policy and training organization in India, replicated the FRONTIERS/IIPS course for 35 state reproductive health program officers. The Institute also introduced OR into its hospital management and epidemiology programs.

- Thirteen participants in the three operations research courses that were evaluated went on to teach the course, or parts of the course, to undergraduate and postgraduate students. 


\section{Scientific writing courses}

- One out of five participants at the writing courses went on to teach the course or parts thereof to undergraduate and postgraduate students and, in one case, to other faculty at her university.

- Audiences in the replicated courses included physicians and HIV/AIDS counselors as well as reproductive health specialists.

- CORT added the writing course to its annual program, beginning in 2007.

The adoption of the courses developed for IIPS by other institutions indicates that the capacity building is cost-effective and meets an important unmet need in South Asia where applied research is not usually a normal part of university curricula, and where there is a need to improve the quality of writing up research results. These needs are felt throughout the research community including at such leading Indian institutions as IIPS and the Institute of Health and Family Welfare.

\section{DISCUSSION AND CONCLUSION}

The capacity building project with IIPS was effective in meeting its objectives. Operations research was incorporated into the organization's graduate program and all scheduled short courses were given. All courses were evaluated positively by participants, who indicated that they made use of the skills they learned when they returned to their jobs. Originally, FRONTIERS aimed at institutionalizing OR capacity at one organization only - the International Institute of Population Studies. By the end of the project, three other organizations - CORT, the National Institute of Health and Family Welfare, and the Medical College of Ahmadabad - had all added OR to their curricula.

FRONTIERS capacity building activities are predicated on the assumption that there is widespread need and demand for OR training including scientific writing. The validity of this assumption is confirmed by high levels of interest in OR capacity building among international organizations such as the UN, WHO, and the Global fund, as well as among national organizations. A second indicator of a need and demand for capacity building is the frequent multiplication of FRONTIERS activities by local organizations.

The capacity building effort has expanded the FRONTIERS research experience and philosophy beyond reproductive health. Although designed for family planning and reproductive health audiences, these have been replicated in India for hospital administrators and epidemiologists, physicians engaged in research in a number of different areas, and HIV/AIDS counselors. 


\section{APPENDIXES}

APPENDIX Ia: Workshop on Developing Operations Research Capacity in South Asia for Program Managers, April 12-15, 2004, Khandala, India

\begin{tabular}{|c|c|c|c|c|}
\hline DATE/TIME & APRIL 12 & APRIL 13 & APRIL 14 & APRIL 15 \\
\hline \multirow[t]{2}{*}{$9: 00$ to $11: 30$} & $\begin{array}{l}\text { Registration (9:00 to } \\
9.30) \\
\text { Welcome } \\
\text { F. Ram }\end{array}$ & $\begin{array}{l}\text { Role of Manager } \\
\text { in Operations } \\
\text { Research } \\
\text { Stacey Gage }\end{array}$ & $\begin{array}{l}\text { Ethics in } \\
\text { Operations } \\
\text { Research } \\
\text { T. K. Roy }\end{array}$ & $\begin{array}{l}\text { Critical Review of } \\
\text { Research Proposal } \\
\text { (Contd). }\end{array}$ \\
\hline & $\begin{array}{l}\text { Inauguration } \\
\text { T. K. Roy } \\
\text { Course Introduction } \\
\text { M. E. Khan } \\
\text { Self Introduction } \\
\text { Experience Sharing } \\
\text { T. K. Roy }\end{array}$ & $\begin{array}{l}\text { Identification of } \\
\text { Problems and } \\
\text { Solutions }\end{array}$ & $\begin{array}{l}\text { Dissemination and } \\
\text { Utilization of } \\
\text { OR }\end{array}$ & $\begin{array}{l}\text { Proposal Committee } \\
\text { Discussion }\end{array}$ \\
\hline $11: 30$ to $11: 45$ & \multicolumn{4}{|l|}{ TEA } \\
\hline $11: 45$ to $1: 00$ & $\begin{array}{l}\text { What is } \\
\text { Operations } \\
\text { Research } \\
\text { James R. Foreit }\end{array}$ & $\begin{array}{l}\text { Indicators } \\
\text { Outputs } \\
\text { Outcomes } \\
\text { Impacts } \\
\text { Stacey Gage }\end{array}$ & $\begin{array}{l}\text { Resources for } \\
\text { Programme } \\
\text { Research } \\
\text { F. Ram }\end{array}$ & $\begin{array}{l}\text { Course Evaluation } \\
\text { Valedictory } \\
\text { M. E. Khan } \\
\text { Vote of Thanks } \\
\text { Chander Shekhar }\end{array}$ \\
\hline $1: 00$ to $2: 00$ & \multicolumn{4}{|l|}{ LUNCH } \\
\hline \multirow[t]{2}{*}{$2: 30$ to $5: 30$} & $\begin{array}{l}\text { Role of Manager } \\
\text { in Operations } \\
\text { Research } \\
\text { F. Ram }\end{array}$ & $\begin{array}{l}\text { Demonstrating } \\
\text { Causality } \\
\text { James R. Foreit }\end{array}$ & $\begin{array}{l}\text { Research } \\
\text { Proposal } \\
\text { M. E. Khan }\end{array}$ & \\
\hline & $\begin{array}{l}\text { Group } \\
\text { Formation }\end{array}$ & $\begin{array}{l}\text { Research } \\
\text { Design } \\
\text { Exercises } \\
\text { M. E. Khan }\end{array}$ & $\begin{array}{l}\text { Critical Review } \\
\text { of Research } \\
\text { Proposal }\end{array}$ & \\
\hline $5: 30$ to $5: 45$ & \multicolumn{4}{|l|}{ TEA } \\
\hline
\end{tabular}


APPENDIX Ib: Workshop on Developing Operations Research Capacity in South Asia for Program Managers, Aug 28-31, 2006, Vadodara, India

\begin{tabular}{|c|c|c|c|c|}
\hline DATE/TIME & AUG 28 & AUG 29 & AUG 30 & AUG 31 \\
\hline 9:00 to $10: 00$ & $\begin{array}{l}\text { Registration (9:00 } \\
\text { to 9.30) } \\
\text { Welcome, } \\
\text { Objectives \& } \\
\text { Inauguration } \\
\text { P.N. Mari Bhat }\end{array}$ & $\begin{array}{l}\text { Role of } \\
\text { Manager in } \\
\text { Operations } \\
\text { Research } \\
\text { ME Khan }\end{array}$ & $\begin{array}{l}\text { Ethics in } \\
\text { Operations } \\
\text { Research }\end{array}$ & $\begin{array}{l}\text { Critical Review of } \\
\text { Research Proposal } \\
\text { (Contd). }\end{array}$ \\
\hline $10: 00-11: 30$ & $\begin{array}{l}\text { Working with } \\
\text { Researchers and } \\
\text { Programme } \\
\text { Managers } \\
\text { ME Khan }\end{array}$ & $\begin{array}{l}\text { Identification of } \\
\text { Problems and } \\
\text { Solutions } \\
\text { F. Ram }\end{array}$ & $\begin{array}{l}\text { Dissemination } \\
\text { and Utilization of } \\
\text { OR } \\
\text { ME Khan }\end{array}$ & $\begin{array}{l}\text { Presentation of the } \\
\text { Review of Research } \\
\text { Proposal } \\
\text { F. Ram }\end{array}$ \\
\hline $11: 30$ to $11: 45$ & \multicolumn{4}{|l|}{ TEA } \\
\hline $11: 45$ to $1: 00$ & $\begin{array}{l}\text { What is } \\
\text { Operations } \\
\text { Research } \\
\text { James R. Foreit }\end{array}$ & $\begin{array}{l}\text { Demonstrating } \\
\text { Causality } \\
\\
\text { James R. } \\
\text { Foreit }\end{array}$ & $\begin{array}{l}\text { Budgeting in } \\
\text { Operations } \\
\text { Research } \\
\text { C. Shekhar }\end{array}$ & $\begin{array}{l}\text { Course Evaluation } \\
\text { Valedictory \& } \\
\text { Certificate } \\
\text { F. Ram } \\
\text { Vote of Thanks } \\
\text { C. Shekhar }\end{array}$ \\
\hline 1:00 to $2: 00$ & \multicolumn{4}{|l|}{ LUNCH } \\
\hline Hy $2: 30$ to $5: 30$ & $\begin{array}{l}\text { Group Formation } \\
\text { Introduction } \\
\text { Case Study I \& II }\end{array}$ & $\begin{array}{l}\text { Indicators } \\
\text { Outputs } \\
\text { Outcomes } \\
\text { Impacts } \\
\text { F. Ram } \\
\begin{array}{l}\text { Research Design } \\
\text { Exercises }\end{array} \\
\text { James R. Foreit }\end{array}$ & $\begin{array}{l}\text { Research } \\
\text { Proposal } \\
\text { F. Ram } \\
\begin{array}{l}\text { Critical Review } \\
\text { of Research } \\
\text { Proposal }\end{array}\end{array}$ & \\
\hline $5: 30$ to $5: 45$ & \multicolumn{4}{|l|}{ TEA } \\
\hline
\end{tabular}


APPENDIX Ic: Workshop on Developing Operations Research Capacity in South Asia for Researchers, December 8-18, 2004, Khandala, India

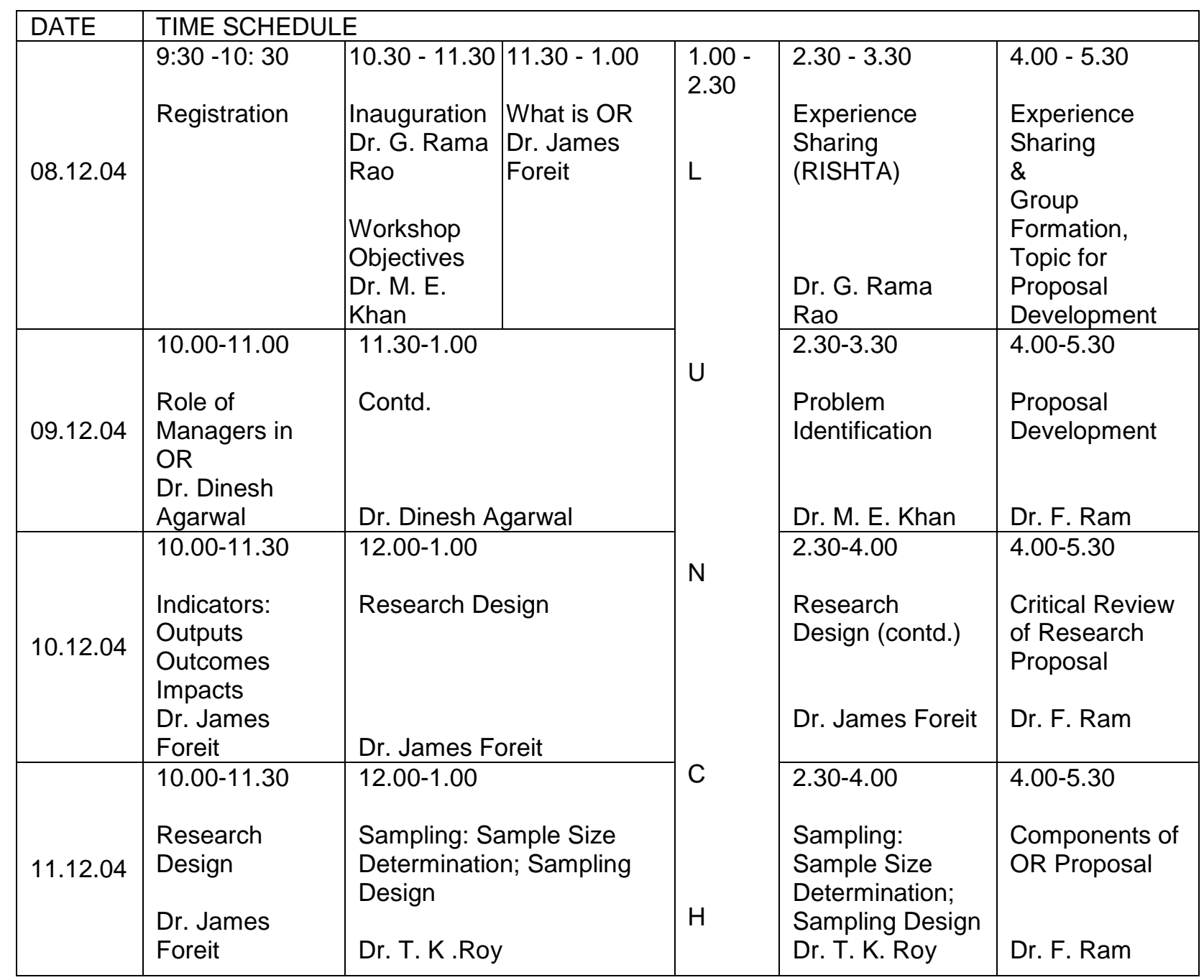




\begin{tabular}{|c|c|c|c|c|c|}
\hline 12.12 .04 & $S$ & $U$ & $1.00-$ & $D$ & $Y$ \\
\hline 13.12 .04 & $\begin{array}{l}\text { 10.00-11.30 } \\
\text { Methods of } \\
\text { Data Collection } \\
\text { (Qualitative) } \\
\text { Dr. M. E. Khan }\end{array}$ & $\begin{array}{c}12.00-1.00 \\
\begin{array}{c}\text { Methods of Data Collection } \\
\text { (Quantitative) } \\
\text { Dr. F. Ram }\end{array}\end{array}$ & 2.30 & $\begin{array}{l}\text { 2.30-4.00 } \\
\text { Willingness to } \\
\text { Pay Survey } \\
\text { Dr. M. E. Khan }\end{array}$ & $\begin{array}{l}\text { 4.00-5.30 } \\
\text { Cost Analysis } \\
\text { Dr. M. E. Khan }\end{array}$ \\
\hline 14.12 .04 & $\begin{array}{l}10.00-11.30 \\
\text { Demonstrating } \\
\text { Causality } \\
\text { Dr. James } \\
\text { Foreit }\end{array}$ & $\begin{array}{c}12.00-1.00 \\
\begin{array}{c}\text { Data Masking \& } \\
\text { Management }\end{array} \\
\text { Dr. Chander Shekhar }\end{array}$ & $\mathbf{U}$ & $\begin{array}{r}2.30 \\
\text { Ethics in OR } \\
\text { stu } \\
\text { Dr. F }\end{array}$ & $\begin{array}{l}5.30 \\
\text { cluding case } \\
\text { 2s) } \\
\text { Ram }\end{array}$ \\
\hline 15.12 .04 & $\begin{array}{c}\text { 10.00-11.30 } \\
\\
\text { Situation } \\
\text { Analysis } \\
\text { Dr. M. E. Khan }\end{array}$ & $\begin{array}{c}\text { 12.00-1.00 } \\
\text { Data Analysis } \\
\text { Dr. Chander Shekhar }\end{array}$ & $\mathbf{N}$ & $\begin{array}{l}2.30-4.00 \\
\text { Data Analysis } \\
\text { (contd.) } \\
\text { Dr. Chander } \\
\text { Shekhar } \\
\end{array}$ & $\begin{array}{c}\text { 4.00-5.30 } \\
\\
\text { Proposal } \\
\text { Development }\end{array}$ \\
\hline 16.12 .04 & $\begin{array}{l}\text { 10.00-11.30 } \\
\\
\text { Dissemination } \\
\text { \& Utilization of } \\
\text { OR } \\
\text { Dr. M. E. Khan }\end{array}$ & $\begin{array}{l}\text { 12.00-1.00 } \\
\text { Up scaling of OR } \\
\text { Dr. M. E. Khan }\end{array}$ & & $\begin{array}{r}2.30 \\
\text { Proposal D }\end{array}$ & $\begin{array}{l}.30 \\
\text { velopment }\end{array}$ \\
\hline 17.12.04 & $\begin{array}{c}10.00-11.30 \\
\text { Final Proposal } \\
\text { Development }\end{array}$ & $\begin{array}{l}\text { 12.00-1.00 } \\
\text { Proposal Presentation }\end{array}$ & C & $\begin{array}{r}2.30 \\
\text { Proposal F }\end{array}$ & 30 \\
\hline 18.12 .04 & \multicolumn{2}{|c|}{$\begin{array}{c}\text { Course Evaluation, Certificate Distribution \& } \\
\text { Vote of Thanks }\end{array}$} & H & & \\
\hline
\end{tabular}




\section{APPENDIX II: List of participants at OR workshops}

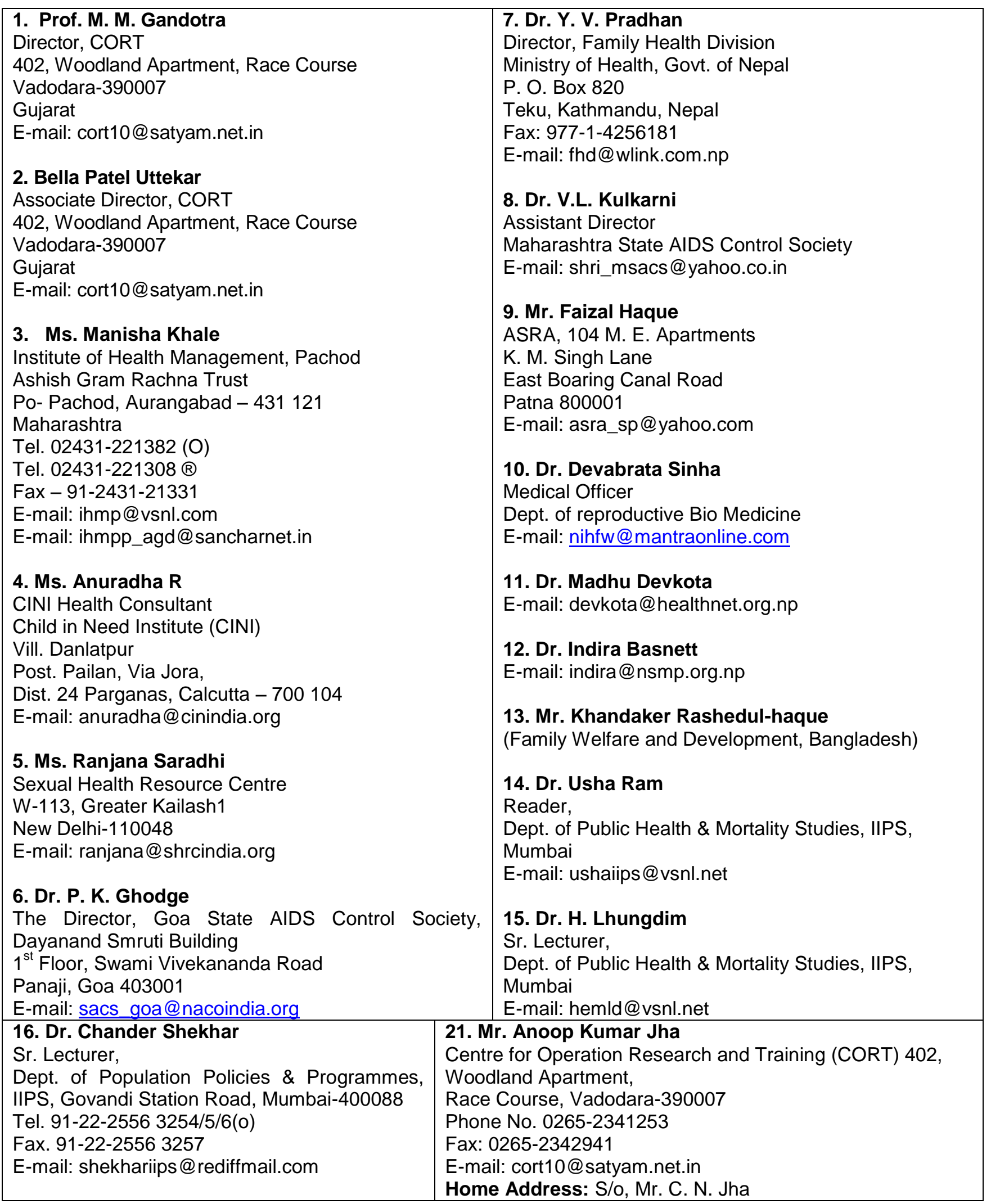




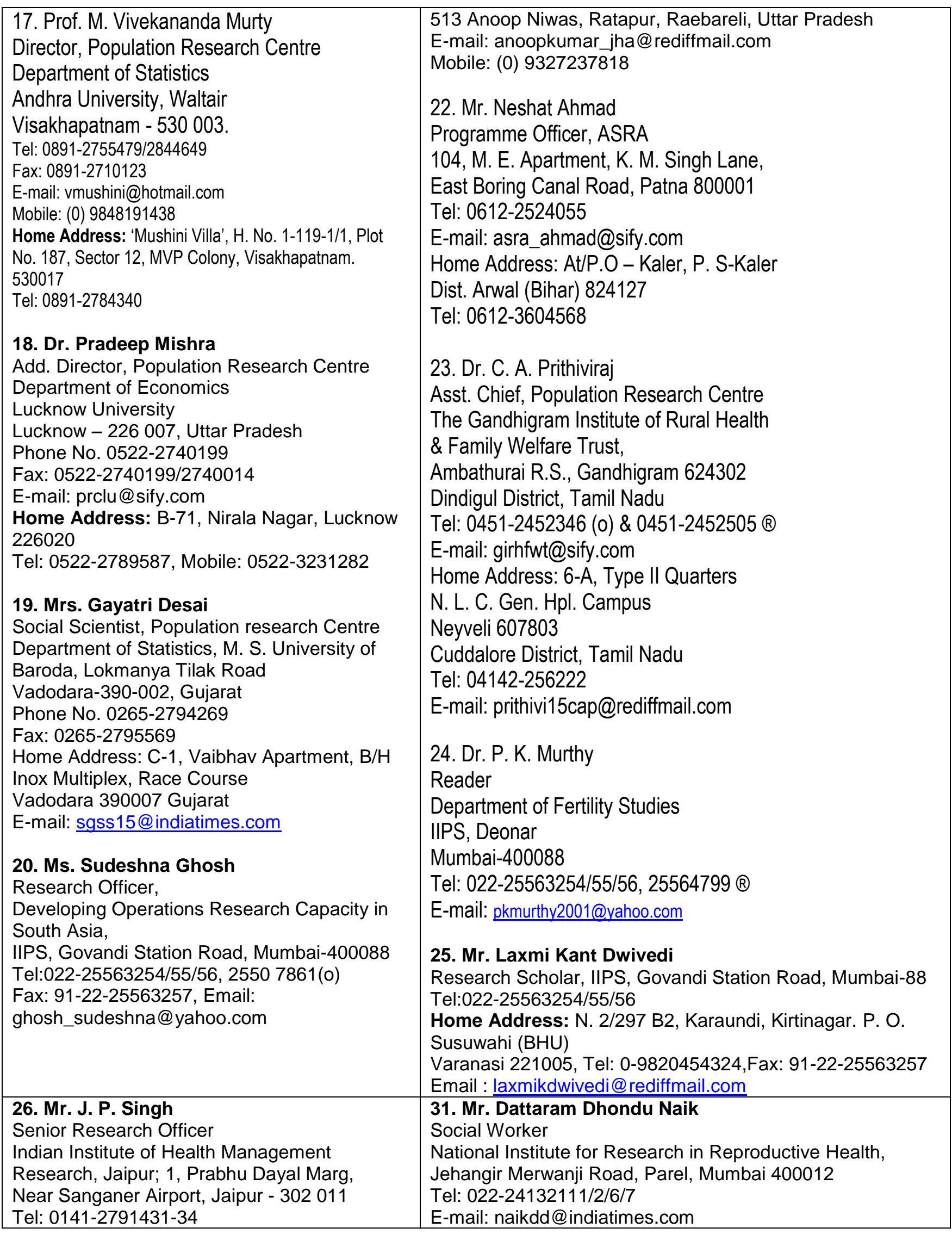


Fax: 91-141-2792138

E-mail: iihmr@iihmr.org

Website: http://www.iihmr.org

Home Address: C-11, Housing Complex, IIHMR 1, Prabhu Dayal Marg,

Near Sanganer Airport, Jaipur - 302011

0141-2791431-34, Ext. 511

E-mail: Jags p71@rediffmail.com

27. Mr. Rajesh Kumar Aggarwal

SRO, Population Research Centre

Centre for Research in Rural and Industrial

Development (CRRID)

2A, Sector 19 A, Madhya Marg,

Chandigarh - 160019

Tel: 0172-2725406

Fax- 0172-2725215

\section{Dr. A. S. Dey}

Dy. Director, PRC, Dept. of Geography

Dr. H. S. Gour University

Sagar-470003, Madhya Pradesh

Tel: 07582-265075

Fax: 07582-265481

E-mail: prcsagar@sancharnet.in

Home Address: A-12, Jai Jalaram Nagar Bh.

Mothers School Gotri Road, Vadodara

Tel: 0265-2330255

E-mail: asdey@yahoo.com

\section{Dr. R. C. Swarankar}

Asst. Professor, Dept. of Anthropology

University of Rajasthan, Jaipur

Ph: 0141-2590567

E-mail: rcswarankar@satyam.net.in

Home Address: 8C/6 Pratap Nagar,

Tonk Phatak, Jaipur 15, Tel: 93145-30110

\section{Dr. S. K. Benara}

Deputy Director (Medical)

Institute for Research in Medical Statistics

Indian Council of Medical Research

Ansari Nagar, New Delhi 110029

Tel: 011-26588905

E-mail: benarask@yahoo.com

Home Address: D2/24/4, DLF, Dilshad Ext. II, Bhopura, Ghaziabad, U. P. 201005

Tel: 011-55790579
Home Address: B/1, Bhandup Ashirwad Coop. Hsg.

Society, Juvekar Marg, Bhandup Village (E), Mumbai 400042

Tel: 022-25653138

32. Dr. V. K. Tiwari

Reader, Acting Head, Dept. of Planning and Evaluation

Sub-Dean, NIHFW, Munirka

New Delhi 110067

Tel: 011-26165959

Fax: 91-11-26101623

E-mail: vktiwari@nihfw.org

Home Address: E-40, NIHFW Campus

Munirka, New Delhi 110067

Tel: 011-26178533

E-mail: vktiwari2@rediffmail.com

\section{Dr. Niraj Kumar}

Project Coodinator,

UNDP-TAHA Project,

Bihar State AIDS Control Society, SIHFW Building,

Sheikhpura, Patna-840014, Email: nirajk2in@yahoo.co.in

Email:pdbhsacs@sify.com

\section{Prof. Arup Maharatna}

Gokhale Institute of Politics and Economics

PUNE 411004, INDIA

Tel: 91-020-25650287; 25671709 ; Fax: 91-020-26552579

Email: arupmaha@yahoo.com

35. Dr. Y.S. Bist

Joint Director

Regional, Health \& Family Welfare Trg. Centre

Dehradun, Uttaranchal-248001

Tel: 0135-2720311; Fax and Tel 0135-2628185

\section{Dr. R.R. Bharti}

Director (Public Health)

Directorate General of Medical \& Health Services

SWASTHYA BHAWAN, Govt. of Uttar Pradesh

Lucknow-226001

Tel-0522-2613923; 0522-2616996; Fax:-2623980

Email:dr_rrbharti@yahoo.com (R): 0522-2616999

\section{Dr. Balbir Singh}

Deputy Director

Directorate Family Welfare Punjab

Parivar Kalyan Bhawan

Secior 34-A

Chandigarh

Tel:91-0172-2609263 


\begin{tabular}{|c|c|}
\hline $\begin{array}{l}\text { 38. Smt. Vimla Nain, } \\
\text { Joint Director (MM \& IEC) } \\
\text { O/O Director General Health Services, } \\
\text { Haryana } \\
\text { Sector-6, Panchkula-134108. } \\
\text { Phone-0172-2581216, 2556704; 9872044466 } \\
\text { Fax No. 0172-2585505 } \\
\text { 39. Dr. Nita Mawar } \\
\text { Deputy Director and Head, } \\
\text { SBR Unit, NARI, Plot No. 73, 'G' Block, MIDC, } \\
\text { Bhosari, } \\
\text { Pune-411026. } \\
\text { Tel: 091-20-27121342, Fax: 27121071 } \\
\text { nmawar@nari.in } \\
\text { 40. Shri. K.K. Panchal } \\
\text { Joint Director (Demography and Evaluation) } \\
\text { Commissionerate of Health, Medical Services } \\
\text { \& Medical Education (HS) } \\
\text { Block No.5/2, } \\
\text { Dr. Jivraj Mehta Bhavan Gandhinagar } \\
\text { Gujarat State. Tel: 91-79-23254548 Fax: } 91- \\
\text { 79-23253304 } \\
\text { Jtdie done health@Gujarat.Gov.in } \\
\text { 41. Ms. Ranjana Jain } \\
\text { Council for Operation Research and Training } \\
\text { 405, Woodland Apartment, Race Course, } \\
\text { Vadodara-390007, Gujarat } \\
\text { Tel-91-265-2341253; Fax; 91-265-2342941 } \\
\text { ranju 1375@rediffmail.com } \\
\text { 42. Mr. Wajahat Ullah Khan } \\
\text { Council for Operation Research and Training } \\
\text { 405, Woodland Apartment, Race Course, } \\
\text { Vadodara-390007, Gujarat } \\
\text { Tel-91-265-2341253; Fax; 91-265-2342941 } \\
\text { Cort10@satyam.net.in } \\
\text { 43. Dr. Lalitha K. } \\
\text { Director, } \\
\text { The Gandhigram Institute of Rural Health \& } \\
\text { Family Welfare Trust, } \\
\text { Gandhigram, Ambathurai, Dindigul District, } \\
\text { Tamil Nadu-624 302 } \\
\text { girhfwt@sancharnet.in } \\
\text { Tel: 0451-2452346/7 Fax-2452347 }\end{array}$ & $\begin{array}{l}\text { 44. Dr. N. S. Bist } \\
\text { Deputy Director } \\
\text { Population Research Centre, Tel: 91-177-2831960; Fax: 91- } \\
\text { 177-2831960; 0177-2802655 (R); Himalaya Pradesh } \\
\text { University } \\
\text { Shimla-171005; prcshimla@yahoo.co.in } \\
\text { 45. Dr. A. S. Day } \\
\text { Deputy Director } \\
\text { Population Research Centre Sagar University, } \\
\text { Sagar, Madhya Pradesh } \\
\text { Tel:91-7582-265075 } \\
\text { Fax: Tel: 91-7582-264581 } \\
\text { 46. Mrs. Varsha Dipak Chitania } \\
\text { PRC Baroda } \\
\text { MS University } \\
\text { Tel: } 91-265-2794269 ; \text { Fax 91-265-2795569 } \\
\text { Gujarat. prcbaroda@yahoo.com } \\
\text { 47. Mr. Mayank Ray } \\
\text { PRC Baroda } \\
\text { MS University } \\
\text { Tel: } 91-265-2794269 ; \text { Fax 91-265-2795569 } \\
\text { Gujarat. prcbaroda@yahoo.com } \\
\text { 48. Dr. (Mrs.) Lalrintulangi } \\
\text { DC (RSS) } \\
\text { Ministry of Health \& Family Welfare } \\
\text { Department of Family Welfare } \\
\text { Government of India } \\
\text { Nirman Bhavan } \\
\text { New Delhi- 110 011 } \\
\text { Fax- 011- 23017292 } \\
\text { E-mail: dcrss@hub.nic.in }\end{array}$ \\
\hline
\end{tabular}




\section{APPENDIX III: List of facilitators for OR and scientific writing workshops}

\begin{tabular}{|c|c|}
\hline $\begin{array}{l}\text { 1. Dr. M. E. Khan } \\
\text { Associate Regional Director } \\
\text { \& Senior Associate } \\
\text { Asia \& Near East Region } \\
\text { Population Council, India } \\
\text { 53, Lodi Estate, New Delhi } 110003 \\
\text { Tel. 91-11-2461 0913/14 } \\
\text { Fax: 91-11-24610912 } \\
\text { E-mail: mekhan@popcouncil.org }\end{array}$ & $\begin{array}{l}\text { 2. Dr. James R. Foreit } \\
\text { Senior Associate, } \\
\text { Population Council } \\
\text { 4301 Connecticut Avenue NW Washington DC } \\
\text { Tel: 1-202-237-9420 Fax: 1-202-237-8410 } \\
\text { E-mail: joreit@pcdc.org }\end{array}$ \\
\hline $\begin{array}{l}\text { 3. Dr. Sharif Md. Ismail Hossain } \\
\text { Project Director, Population Council } \\
\text { South \& East Asia- Bangladesh Office } \\
\text { House CES (B) 21, Road } 118 \\
\text { Gulshan, Dhaka, Bangladesh } \\
\text { Tel: (880) (2) } 8821227 / 8826657 \\
\text { (880) (2) 8811964/8812384 } \\
\text { Facsimile: (880) (2) } 8823127 / 8823132 \\
\text { E-mail: drsharif@pcdhaka.org } \\
\text { Web: http://www.popcouncil.org }\end{array}$ & $\begin{array}{l}\text { 4. Dr. F. Ram } \\
\text { Prof. \& Head } \\
\text { Dept. of Fertility Studies } \\
\text { IIPS, Govandi Station Road, } \\
\text { Mumbai-400088 } \\
\text { Tel. 91-22-2550 7861(o) } \\
\text { Fax. 91-22-2556 3257 } \\
\text { Mobile 9819371996 } \\
\text { E-mail: fram@vsnl.com }\end{array}$ \\
\hline $\begin{array}{l}\text { 5. Dr. T. K. Roy } \\
\text { Ex-Director \& Sr. Prof. } \\
\text { IIPS, Mumbai } \\
\text { E-mail: diriips@vsnl.com }\end{array}$ & $\begin{array}{l}\text { 6. Prof. G. Rama Rao } \\
\text { Officiating Director } \\
\text { IIPS, Govandi Station Road, Mumbai-400088 } \\
\text { Tel No. } 91-22-25563254 / 55 / 56 \\
\text { Fax. } 91-22-25563257\end{array}$ \\
\hline $\begin{array}{l}\text { 7. Dr. Dinesh Agarwal } \\
\text { UNFPA, 53 Jorbagh } \\
\text { New Delhi-110003 } \\
\text { Tel No. (011) } 24649247,24627986 \\
\text { Fax: } 91-11-24641679\end{array}$ & $\begin{array}{l}\text { 8. Dr. Laishram Ladusingh } \\
\text { Prof. Dept. of Mathematical } \\
\text { Demography and Statistics } \\
\text { IIPS, Deonar } \\
\text { Mumbai-400088 } \\
\text { Tel: (-022) } 25563254 / 55 / 56 \\
\text { Fax. } 91-22-25563257\end{array}$ \\
\hline $\begin{array}{l}\text { 9. Dr. Anastasia J. Gage } \\
\text { Associate Professor } \\
\text { Department of International Health and } \\
\text { Development, } \\
\text { Tel: } 504-584-3647 \\
\text { Fax: } 504-584-3653 \\
\text { Email: agage@tulane.edu }\end{array}$ & $\begin{array}{l}\text { 10. Dr. (Mrs.) Usha Ram } \\
\text { Reader, Dept. of Public Health \& Mortality Studies } \\
\text { IIPS, Govandi Station Road, Mumbai-400088 } \\
\text { Tel. } 91-22-25563254 / 5 / 6(0), 25561570 \AA \\
0-9819371996 \\
\text { Fax. } 91-22-25563257 \\
\text { E-mail: ushaiips@vsnl.net }\end{array}$ \\
\hline $\begin{array}{l}\text { 11. Dr. Chander Shekhar } \\
\text { Sr. Lecturer, } \\
\text { Dept. of Population Policies \& Programmes, } \\
\text { IIPS, Govandi Station Road, Mumbai-400088 } \\
\text { Tel. } 91-22-25563254 / 5 / 6(0) \\
\text { Fax. } 91-22-25563257 \\
\text { E-mail: shekhariips@rediffmail.com }\end{array}$ & $\begin{array}{l}\text { 12. Mr. Jitendra Khanna, } \\
\text { Technical Officer, } \\
\text { WHO, Geneva } \\
\text { Switzerland } \\
\text { E-mail; khannai@who.int }\end{array}$ \\
\hline
\end{tabular}




\section{APPENDIX IV: List of Participants for Scientific Writing Workshop at IIPS (16-19 May}

2006)

\begin{tabular}{|c|c|c|}
\hline Name & Electronic Address /email & $\begin{array}{l}\text { Name and Address of } \\
\text { Organization }\end{array}$ \\
\hline 1. Dr. N. Mawar & nmawar@nariindia.org & \multirow{2}{*}{$\begin{array}{l}\text { National Aids Research } \\
\text { Institute, } 734 \text { Block, MIDC } \\
\text { Bhosari, Pune } 411026 .\end{array}$} \\
\hline 2. Dr. S. Joshi & sjoshi@nariindia.org & \\
\hline 3. Dr. N.R.K. Behera & fwtrc@indiatimes.com & \multirow{2}{*}{$\begin{array}{l}\text { Family Welfare Training } \\
\text { and Research Centre 332, } \\
\text { SVP Road Mumbai-4. }\end{array}$} \\
\hline 4. Dr. Sumita Ghosh & mailboxss@indiatimes.com & \\
\hline 5. Mr. D Balaiah & balaiah1954@yahoo.com & \multirow{3}{*}{$\begin{array}{l}\text { National Institute for } \\
\text { Research in Reproductive } \\
\text { Health Parel Mumbai-400012. }\end{array}$} \\
\hline 6. Dr. Clara Aranha & clara aranha@rediffmail.com & \\
\hline 7. Ms. Stuti Rastogi & stuti.rastogi17@rediffmail.com & \\
\hline 8. Dr. Bela Patel & cort10@satyam.net.in & \multirow{2}{*}{$\begin{array}{l}\text { Cort, 4-floor woodlands } \\
\text { apprts race course Vadodra } \\
390007 .\end{array}$} \\
\hline 9. Dr. Sandhya Barge & cort10@satyam.net & \\
\hline 10. Dr. Mary Sebastian & msebastian@popcouncil.org & $\begin{array}{l}\text { Population Council } 53 \text { Lodi } \\
\text { Estate New Delhi-3 }\end{array}$ \\
\hline 11. Ms. Asha Mukundan & kpasha@tiss.edu & $\begin{array}{l}\text { Tata Institute of Social Sciences } \\
\text { Sion-Trombay Road Deonar. }\end{array}$ \\
\hline 12. Ms. Vini Sivangndan & vinisivangndan@yahoo.com & \multirow{2}{*}{$\begin{array}{l}\text { Gokhale Institute of Politics \& } \\
\text { Economics, near Deccan } \\
\text { Gymkhana, Pune-411004. }\end{array}$} \\
\hline 13. Dr. P. Ramesh & ramesh.poluru.@gmail.com & \\
\hline 14. Dr. B. Paswan & bpaswan@yahoo.com & \multirow{6}{*}{$\begin{array}{l}\text { International Institute for } \\
\text { population Sciences, Govandi } \\
\text { Station Road, Deonar Mumbai- } \\
4000088 \text {. }\end{array}$} \\
\hline 15. Dr. Rajiva Prasad & rajivprasad@yahoo.co.in & \\
\hline 16. Dr. K.C.Das & daskc@yahoo.co.in & \\
\hline 17. Mr. Abhishek Singh & abhi iips@yahoo.co.in & \\
\hline 18. Ms. B. Amenla Nuken & amenlanukein@hotmail.com & \\
\hline $\begin{array}{l}\text { 19. Mr. Laxmi Kant } \\
\text { Dwivedi }\end{array}$ & laxmikdwivedi@rediffmail.com & \\
\hline $\begin{array}{l}\text { 20. Mr. Suvakant N. } \\
\text { Swain }\end{array}$ & mail2shubh@gmail.com & \multirow{3}{*}{$\begin{array}{l}\text { International Institute for } \\
\text { population Sciences, Govandi } \\
\text { Station Road, Deonar Mumbai- } \\
4000088 \text {. }\end{array}$} \\
\hline $\begin{array}{l}\text { 21. Mr. Dhananjay } \\
\text { Bansod }\end{array}$ & dbansod@gmail.com & \\
\hline 22. Ms. Ruchi Jain & ruchi iips@yahoo.co.in & \\
\hline
\end{tabular}




\section{APPENDIX V: Skills learned in OR courses were used by participants for conducting research}

\section{Titles of OR Studies}

1. Prevalence of eye problems in school going children of Baroda - OR study

2. Study on social marketing of condoms among female sex workers - OR study

3. Male involvement in reproductive health - OR study

4. Enhancing IUD Use in Gujarat - OR study

5. Increasing public-private partnership in RNTCP and testing model in Alwar district of Rajasthan - OR study

6. Health delivery system in India - OR study

7. Operations research on the adolescents reproductive health (ARH) comic books - OR study

8. Evaluation of media impact on sexual health of adolescents

9. KAP of water-borne and vector-borne diseases among people of urban areas

10. Evaluation of IMNCI (Integrated Management of Neonatal and Childhood Illness) Program

11. Intervention by way of effective motivation at TB clinics- Can this help reduce smoking among TB patients? OR study

12. Effective counseling at RNTCP clinics-Could this enhance HIV testing among TB patients? OR study 


\section{APPENDIX VI: Skills learned from scientific writing course were used by participants for writing journal articles and reports/updates}

\section{Journal articles (National)}

1. Maitra, Nandita and Monika Gupta. Sero-prevalance and correlates of herpes simple's virus type 2 infection in a general gynecology clinic. Archives Obit Gynae, 2007; Vol 275 (1) 19-23;

2. Maitra, Nandita, NS Shah, RN Verma and VA Desai. Dopler ultrasound of the uteroplacental and fetal arterial circulation in the prediction of growth restriction and adverse prenatal outcome. International Journal of Gyn and Obst. (India) 2006; 9(5): 2932 ;

3. Maitra, Nandita, AN Shah and RV Bhatt. Electronic fetal monitoring. International Journal of Gyn and Obst. (India) 2006; 9(6):55-59;

4. Maitra, Nandita and Ruta Gokani. Liver diseases in pregnancy leading to emergencies. Emergencies in Ob and Gyn Edited by Charu Mittal, Prabudh Mittal, PeePee Publishers and Distributors Ltd., New Delhi 2006;

5. Chellapan, K, S Aggarwal and N Maitra. Recent trends in obstetruics \& gyn Edited by Pankaj Desai, B.I. Publications Pvt. Ltd, New Delhi, 2007

6. Khan, M.E. and Aditi Aeron. Prevalence, nature and determinants of violence against women in Bangladesh. Journal of FW, Vol 52 Sp Issue 2006

7. Barge, Sandhya. Medical termination of pregnancy in the private sector.Journal of FW, Vol 52, Sp Issue, 2006.

8. Ramesh, P., 2007, An Analysis of Fertility Differentials among Caste Groups in Andhra Pradesh, Working Paper No. 12, Gokhale Institute of Politics and Economics, Pune, India. http://www.gipe.ernet.in/pdfs/working\%20papers/wp12_\%20pramesh.pdf

9. Ramesh, P., 2006, Malnutrition among women in Kerala: Trends, and Determinants. Working Paper No. 7, Gokhale Institute of Politics and Economics, Pune, India. http://www.gipe.ernet.in/working\%20paper/ramesh_working\%20paper.pdf 


\section{International journal articles}

1. Groce, Nora, Nita Mawar and Marina MacNamara. Inclusion of AIDS educational messages in rites of passage ceremonies: Reaching adolescents in tribal communities, Culture, health and Sexuality, 2006, 8: 303-315;

2. Mawar, N, PL Joshi, S sahay, RD Bagul, and RS Paranjype, Concerns and experiences of women in participatying in short-term AZT intervention feasibility study for the prevention of HIV transmission from mother to child and future implications, Culture, Health and Sexuality. 2007, 9(2): 199-207;

\section{Reports/Updates}

1. Infant and Child Mortality in Gujarat, 2002-04: Emerging Trends and Determinants, Aug 2006; 2. The Impact of RCH Programme on Fertility and Mortality to Achieve Replacement Level Fertility in India. A district Level Analysis, Sept 2006;

2. Mawar, Nita. Need for understanding the concerns of women participating in a trial: Perspectives of women participating in an AZT feasibility study, paper presented at ICMR-MDP workshop, 5-6 Dec, 2005, New Delhi and published in the report pp24-29

3. Region and Community Specific Life Tables for India, 1991-98, Use of Repeat Surveys of the Same Population to Maximize Precision of the Estimates, Jan 2007.

4. Enhancing participation of men in RH: An intervention study in urban slums of Mumbai; Integrating RTI/STI and HIV services with SRH through MCMG health posts

5. Understanding Contraception Use among Muslims of India, Pakistan and Bangladesh; Contraceptive Use in India: A Multivariate Decomposition and Related Simulation Analysis

6. Importance of Community Level Effects in Explaining the Fertility of Rural India: A Comparative Study under Multiple Linear and Multilevel Multiple Linear Regression Analysis;

7. Reproductive Health Problems Among Urban Women: A Study of Four Metro Cities in India;

8. Tourism and Sexual Behavior: Experiences of Youths in Goa; Reproductive Morbidity among Tribal and Non-tribal Women in India: A Special Focus to Domestic Violence; Age Reporting in Census: An Insight; Migration and Nutritional Status of Women in India

9. A Study of RH Health Problems Among Men and Women in Urban Slums with Spl. Reference to STI. May 2007 
10. Non-scalpel vasectomy and client satisfaction in AP

11. Integrated management of neonatal and childhood illnesses, INCLEN. Baseline assessment of childhood morbidity and mortality in Parbhani district of Maharashtra. 2007.

12. Report on Women and AIDS study; Stigma and discrimination.

13. Promoting healthy timing and spacing of pregnancy in India through integrated public delivery systems. 2007. FRONTIERS Update No [] New Delhi: Population Council.

14. Knowledge, Attitude and Beliefs about Sexual and Reproductive Health among the Members of Nehru Yuva Kendra;

15. Post Tsunami relief to development program in Andhra Pradesh; Assessment of ASHA and JSY in Madhya Pradesh, Orissa, and Rajasthan;

16. Needs assessment of Street children; Assessment of ASHA and JSY in Assam, Himachal Pradesh, and West Bengal for GTZ;

17. Baseline survey of sexual and reproductive health status of women, men, and adolescents in 7 states of India, FPAI;

18. Assessment of ASHA and JSY in Uttar Pradesh and Bihar

19. Assessment of Cervicovaginal Cytokine Levels Following Exposure to Nisin Gel Formulation in Rabbits. Conference Proceedings: Action to Strengthen Linkages between SRH and HIV/AIDS, India. 